\title{
ENFORCING THE CLIMATE CHANGE ACT
}

\author{
Jonathan Church*
}

\begin{abstract}
This paper examines the enforceability of the duties in the Climate Change Act 2008 which require the UK's GHG emissions to be reduced over time. Section B highlights how the Act's other provisions must be interpreted so as to give proper support to these duties. The paper goes on, in Section $\mathrm{C}$, to dispute objections that have been made to the duties' enforceability - on the grounds that they are 'target duties' or 'non-justiciable'- and argues that the courts can enforce them provided they adopt the amplified role which this new kind of duty requires; by seeking to forge effective but appropriate remedies. Section D suggests what form these remedies might take. Final conclusions are described in Section E.
\end{abstract}

\section{A. INTRODUCTION}

The UK Climate Change Act 2008 ('the Act') has been described as 'historic', 1 'revolutionary', ${ }^{2}$ a 'world leader in climate change legislation', ${ }^{3}$ and 'the most advanced climate change legislation in the world'. ${ }^{4}$ Arguably the Act's most noteworthy feature is the legal duty requiring the reduction of UK greenhouse gas (' $\mathrm{GHG}$ ') emissions by $80 \%$ by 2050 as compared with 1990 levels. ${ }^{5}$ However, the legal effect of this duty is widely contested. This article defends the assertion made repeatedly by Government in pre-legislative scrutiny that this duty - alongside an equivalent duty to ensure certain GHG emission reductions in consecutive 5 -yearly budgetary periods ${ }^{6}-$ is 'legally enforceable'. ${ }^{7}$ These two duties are referred to as the Act's 'primary duties' and the targets they relate to as the '2050 target' and the 'carbon budgets', respectively.

Before examining these primary duties, however, I assess the role of other duties in the Act which govern how carbon budgets are set and amended. ${ }^{8}$ If these were to be

\footnotetext{
${ }^{*}$ MSci, MA (Cantab), LLB (UOL), LLM (UCL); Lawyer at ClientEarth.

${ }^{1}$ Matthew Lockwood, 'The political sustainability of climate policy: The case of the UK Climate Change Act' (2013) 23 Global Environmental Change 1339, 1339.

2 ibid.

${ }^{3}$ Richard Macrory, 'The UK Climate Change Act - Towards A Brave New Legal World?' in Inge Lorange Backer and others (eds), Pro Natura (University of Oslo 2012) 306, 306.

${ }^{4}$ Sam Fankhauser, David Kennedy and Jim Skea, 'The UK's carbon targets for 2020 and the role of the Committee on Climate Change' in Anthony Giddens, Simon Latham and Roger Liddle (eds), Building a lowcarbon future: The politics of climate change (Policy Network 2009) 99-100.

${ }^{5}$ Climate Change Act 2008 s 1(1).

${ }^{6}$ ibid s 4(1)(b).

${ }^{7}$ Department for Environment, Food and Rural Affairs, Taking Forward the UK Climate Change Bill: The Government Response to Pre-Legislative Scrutiny and Public Consultation (Cm 7225, 2007) 23, 53, $97,133$.

${ }^{8}$ Importantly, the Act establishes a number of further duties (beyond the scope of this article) which form a system of governance to ensure periodic and thorough oversight of Government actions by the CCC and
} 
interpreted unduly softly then the primary duties would be vitiated, however enforceable they may be. I then argue that the primary duties should be treated as absolute duties before considering whether they are enforceable in those terms. I find that widely proffered elements of non-justiciability would apply only falteringly to a judicial review claim in respect of what is a new kind of legal duty, and identify an alternative framework of analysis that may be more useful. My conclusion is that objections to enforceability can be overcome by the development of suitable remedies, the possible form(s) of which I attempt to sketch out.

Much of the discussion assumes as context an imagined judicial review claim brought explicitly to enforce the Act's duties. However, this is certainly not to suggest that the Act is not capable of being invoked in other legal contexts or that it does not have wider influence or significance. 9

\section{B. SETTING AND AMENDING THE PRIMARY DUTIES' TARGETS}

\section{The breadth of the Secretary of State's discretion in principle and practice}

Progress towards the 2050 target is structured by 5-yearly budgetary periods which stretch from 2008-2012 to 2048-2052 (and, in theory, beyond ${ }^{10}$ ). It is fundamental to the effectiveness of the Act that these carbon budgets do indeed chart an appropriate - gradual and cost-effective - course which keeps its sights on the 2050 target. In principle, given the low political salience of climate change, ${ }^{11}$ it may well be tempting for successive Secretaries of State to set insufficiently ambitious carbon budgets which allow their trajectory, over time, to deviate increasingly from the 2050 target. ${ }^{12}$ Doing so would make the 2050 target increasingly unobtainable and could potentially endanger the sustainability of the Act itself. However, in practice, the Secretary of State's discretion is likely to be constrained. The

Parliament; central to keeping progress on track and thereby avoiding the eventual breach of a primary duty. In particular: ss 16, 18, 36, 37.

${ }^{9}$ The High Court has suggested that the Act may function as a kind of relevant consideration in the development of national planning policy: $R$ (London Borough of Hillingdon) $v$ Secretary of State for Transport, [2010] EWHC 626; Macrory (n 3) 317-320. In light of the Supreme Court's endorsement of Lord Justice Laws' judgment in Thoburn v Sunderland CC [2002] EWHC 195 (Admin), [58] - [70], it is conceivable that the Act might take its place within a hierarchy of constitutional statutes, thereby prevailing over subsequent statutes that might conflict with certain of its provisions: $R$ (Buckinghamshire CC) v Secretary of State for Transport, [2014] UKSC 3 [208]; Aileen McHarg, 'Climate change constitutionalism? Lessons from the United Kingdom' [2011] Climate Law 469; David Feldman, 'The nature and significance of "constitutional” legislation' [2013] LQR 343. The possible influences of EU and human rights law are not considered in this article.

${ }^{10}$ This is clear from the Act s 5(1)(c).

${ }^{11}$ Lockwood (n 1) 1341-1343.

12 The carbon budgets are otherwise only anchored to legal waypoints at two points - the carbon budget including the year 2020 (the third carbon budget, at 34\%: s 5(1)(a) and The Climate Change Act 2008 (2020 Target, Credit Limit and Definitions) Order, SI 2009/1258) and the year 2050 (at 80\%: s 5(1)(b)). Both 'anchors' are themselves open to amendment: ss 6(1)(a), 2(1)(a). 
extent of that constraint is considered here, first in terms of the setting of carbon budgets and secondly in terms of their amendment.

On a literal reading of the Act, the Secretary of State is afforded a relatively wide discretion in setting the level of carbon budgets, something he must do in the twelfth year before the start of each budgetary period. ${ }^{13}$ When doing so, he must 'take into account' certain specified considerations. ${ }^{14}$ These include but are not limited to: scientific knowledge about climate change; economic and fiscal circumstances; circumstances at European and international level; and the advice which the Committee on Climate Change (CCC) is required under the Act to provide. ${ }^{15}$ However this duty to take into account does not, prima facie, translate into a duty to give particular weight to any one consideration over another. ${ }^{16}$ Similarly, while carbon budgets must be set 'with a view to meeting' the 2050 target, ${ }^{17}$ this wording could suggest that meeting the 2050 target must only be at least one of the Secretary of State's objectives; it need not be his primary purpose. ${ }^{18}$

Given the centrality of carbon budgeting to the Act as a whole, such discretion in setting carbon budgets would arguably be unduly wide. It would imply that the Secretary of State could prioritise (say) economic considerations above all others in setting a carbon budget, or another consideration not specified in the Act. ${ }^{19}$ Could he take into account a personal doubt over the existence of anthropogenic climate change, or a belief that the consequences of climate change would be beneficial to the UK? Might he adopt as his primary purpose in setting a carbon budget not the need to meet the 2050 target but the protection of the UK's oil and gas industry? ${ }^{20}$

In practice, we may expect that the Secretary of State's discretion in setting carbon budgets would not be nearly so wide. His decisions will be constrained by the normal bounds of illegality which require that factors taken into consideration in any decision and any purpose for which a decision is made, must not depart too far from the purpose ascribed to the Act as a whole. ${ }^{21}$ Furthermore, English law no longer elevates a 'plain meaning'

\footnotetext{
13 s 4(2)(b).

${ }^{14}$ ss $10(1),(2)(a)-(i)$.

${ }^{15}$ s $9(1)(\mathrm{a})$.

${ }^{16}$ Paul Craig, Administrative Law (Sweet \& Maxwell 2012) 573.

${ }^{17}$ ss $8(2)(\mathrm{b}), 13(2)(\mathrm{a})$.

${ }^{18}$ If, at least, the treatment of 'with a view to' in $R v$ Dooley [2005] EWCA Crim 3093 [13]-[14], is followed.

19 The list of mandatory considerations in the Act is not exhaustive: $\mathrm{s} 10(7)$.

20 (To borrow wording from s 10(2)(c)).

${ }^{21}$ eg Craig (n 16) - respectively: ch. 19-010 (572-575); ch. 19-009 (568-572).
} 
interpretation of a statutory provision above a purposive reading of it. ${ }^{22}$ The purpose of the Act will be a matter of construction for the court. ${ }^{23}$ In this regard, the 2050 target has such a central prominence in the $\operatorname{Act}^{24}$ (aside from it being section 1(1)) that it can be expected to play a key role in informing the court's interpretation of the provisions described above; provisions which are plainly intended to support and facilitate the achievement of the 2050 target. The particular clarity of the Climate Change Act's purpose is another factor likely to constrain the discretion afforded to the Secretary of State in taking decisions pursuant to it. For these reasons, the hypothetical examples given above would, in all likelihood, be deemed to involve the unlawful exercise of discretion, even though they may not offend a literal reading of the Act.

The weight that the Secretary of State is entitled to give to different considerations is also likely to be constrained by how far each consideration departs from the Act's overall purpose. The Secretary of State will likely be required to take meeting the 2050 target as his primary consideration in setting a 2050 target, rather than it being one among many.

Similar arguments apply to the Secretary of State's power to amend a carbon budget once it has been set. Amendment is permitted if it 'appears to the Secretary of State that, since the budget was originally set (...) there have been significant changes affecting the basis on which the previous decision was made'. ${ }^{25}$ These words imply that the presence of such 'significant changes' will be determined subjectively by the Secretary of State; in other words that they are not 'precedent facts', the established absence of which could lead a court to quash a decision which has been based on their existence. ${ }^{26}$ However, such an interpretation has been doubted by the CCC. In 2011, when the level of the fourth carbon budget (relating to the period 2023-2027) was set, ${ }^{27}$ the Government stated its intention to revisit it 'by 2014' - and, potentially, to 'revise up our budget' ${ }^{28}$ to ensure it remained aligned with the

\footnotetext{
${ }^{22}$ Indeed, statutory interpretation has evolved to the point where 'literalism should give way to purposive interpretation as a matter of course and not exception': Jeff King, Judging Social Rights (CUP 2012) 197, citing Michael Zander, The Law Making Process (6th edn, CUP 2004) 132-149.

${ }^{23}$ Padfield v Minister of Agriculture, Fisheries and Food [1968] AC 997 (HL) [1030].

${ }^{24}$ In addition, a description of section 1 forms the first sentence of the Act's long title.

${ }^{25}$ s 21(2). Again, the CCC's advice must be taken into account: s 22(1)(a). Note that similar provision is made for the amendment of the 2050 target - though in this case the 'significant developments' are restricted to those in scientific knowledge about climate change or European or international law or policy (ss 2(1)(a), 2(2)(a)).

${ }^{26}$ Jonathan Auburn, Jonathan Moffett and Andrew Sharland, Judicial Review; Principles and Procedure (OUP 2013) 460: 'It is almost inconceivable that a statutory provision phrased in [such] subjective terms ... could ever give rise to an issue of precedent fact' (citing $R v$ Home Secretary ex parte Zamir [1980] AC 930 (HL) [948]).

${ }^{27}$ The Carbon Budget Order 2011, SI 2011/1603.

28 'Revise up': ie allow for greater GHG emissions.
} 
reductions trajectory of the EU Emission Trading Scheme. ${ }^{29}$ The original basis for the fourth carbon budget, as well as the 'significance' of any changes since, would have been factually and legally arguable. However, the $\mathrm{CCC}$, as the mandatory consultee, repeatedly warned against any amendment to the budget. ${ }^{30}$ Importantly for current purposes, it did so in terms which treat the existence of 'significant developments' as an objective test: '[o]nly if there is a significant change [in the circumstances upon which the budget was set], demonstrable on the basis of evidence and analysis, can the budget be changed' ${ }^{31}$ In the event, the fourth carbon budget was retained (not on the basis of this point of interpretation). ${ }^{32}$ It is likely, however, that the setting and maintenance of a fifth carbon budget - in 2016 - will be at least as contentious as the fourth, in which case such legal distinctions may take on greater practical importance and may be more forcefully contested.

There will also be implied restrictions on the Secretary of State's power to amend a carbon budget. It is submitted, for example, that the Act cannot intend that the Secretary of State would have greater freedom to amend a target than to set it in the first place, as this would allow the provisions governing the setting of carbon budgets to be effectively bypassed. ${ }^{33}$ It must be implicit therefore that the 'significant developments' changing the basis on which a target was originally set (whether they need to be established objectively or subjectively) must relate to - and in some sense be proportionate to - the proposed amendment to the target. The same may be said for any amendment of the 2050 target itself; such amendments being permitted on the basis of certain kinds of 'significant developments', provided those developments 'make it [the particular amendment] appropriate', ${ }^{34}$ in the context of the Act as a whole.

\footnotetext{
${ }^{29}$ HM Government, Policy Statement: Implementing the Climate Change Act 2008: The Government's proposal for setting the fourth carbon budget (May 2011) [17].

${ }^{30}$ Letter from Lord Deben (CCC) to Ed Davey MP: 3 October 2013 <http://www.theccc.org.uk/wpcontent/uploads/2013/10/Ed-Davey-October13-final.pdf> accessed 19 January 2015; Letter from Lord Deben (CCC) to Ed Davey MP 1 July 2013 ('If there has been no change in circumstances, then the budget cannot be changed') <http://www.thecc.org.uk/wp-content/uploads/2013/07/4CB_Call_for_Evidence_letter_ED_letter_1_July.pdf $>$ accessed 19 January 2015.

${ }^{31}$ Committee on Climate Change, Meeting Carbon Budgets - 2014 Progress Report to Parliament, July 2014,8 <http://www.theccc.org.uk/wp-content/uploads/2014/07/CCC-Progress-Report-2014_web_2.pdf> accessed 19 January 2015.

${ }^{32}$ Ed Davey MP, Written Ministerial Statement: Review of the Fourth Carbon Budget, 22 July 2014 <http://www.parliament.uk/documents/commons-vote-office/July-2014/22\%20July\%202014/14-DECCCarbonBudget.pdf $>$ accessed 19 January 2015.

${ }^{33}$ Indeed, the same matters are required to be taken into account in amending a carbon budget as they are in setting one, pursuant to $\mathrm{s} 10(1)(\mathrm{a})$.

${ }^{34}$ s $2(2)(a)$.
} 
The final constraint on all such decisions is democratic: carbon budgets are set and amended by Order, subject to 'a resolution of both houses of Parliament'. ${ }^{35}$ If the carbon budget set by the Secretary of State differs from that recommended by the $\mathrm{CCC},{ }^{36}$ he must publish a statement setting out the reasons why. ${ }^{37}$ This requirement is important from the perspective of public accountability. It is also important legally, since any reasons given by the Secretary of State may be subject to judicial review. At the very least, these reasons must not be Wednesbury unreasonable or made in bad faith. While this normally represents a very high threshold, it could be argued that it should be deployed in its 'anxious scrutiny' form where 'issues of public importance' are raised (as would arguably be the case here).$^{38}$ In short, the Secretary of State's discretion in setting and amending carbon budgets should in practice be narrower than a literal reading would suggest, given the clear purpose of the Act as a whole. ${ }^{39}$

\section{Policing and constraining this discretion in the courts}

In practice, the precise contours of the Secretary of State's powers are likely to be established in the courts, specifically by a claim in judicial review. Whilst the susceptibility to judicial review of the Act's primary duties is contested (as discussed in the sections that follow) there should in principle be no such obstacle as regards the enforcement of the Secretary of State's discretion to set and amend carbon budgets. ${ }^{40}$ In particular, standing should not be an obstacle to a claim. ${ }^{41}$ Questions of timing should be straightforward since a claim will relate to a specific decision by the Secretary of State or his failure to take a decision required by a particular time. Similarly, the nature of a remedy, if awarded, is unlikely to be contentious. In practical terms, however, the result might represent something of a hollow victory - if, say, an action/decision taken unlawfully was quashed, ${ }^{42}$ potentially to be re-taken lawfully to give the same result. Nonetheless, a court's interpretation of some of the important provisions described above could have important consequences for the success of the Act in the long-

\footnotetext{
${ }^{35} \mathrm{ss} 8(3), 21(5)$, according to the 'affirmative resolution procedure' (s 91).

${ }^{36}$ ss 34(1)(a), 21(1)(a).

${ }^{37}$ ss $9(4), 22(7)$.

${ }^{38}$ David Thomas, 'How Irrational Does Irrational Have To Be? Wednesbury in Public Interest, Non-Human Rights Cases' [2008] JR 258, 265.

${ }^{39}$ Such an approach is exemplified by Padfield (n 23).

${ }^{40}$ The same can be said of ensuring that the Secretary of State adheres to the Act's broader framework of governance - see (n 8).

${ }^{41}$ Colin T Reid, "A new sort of duty? The significance of "outcome duties" in the Climate Change and Child Poverty Acts' [2012] PL 749, 757-8.

42 Joint Committee on the Draft Climate Change Bill, Oral and Written Evidence (second report); Draft Climate Change Bill (2006-7, HL 170-II, HC 542-II) 239-240 (Evidence of Christopher Forsyth).
} 
term. In turn, this could help to ensure that carbon budgets chart an appropriate and costeffective course towards the 2050 target.

\section{ENFORCING THE PRIMARY DUTIES}

Section 1(1) of the Act reads: 'It is the duty of the Secretary of State to ensure that the net UK carbon account for the year 2050 is at least 80\% lower than the 1990 baseline'. Section $4(1)(b)$ is precisely equivalent: 'It is the duty of the Secretary of State (...) to ensure that the net UK carbon account for a budgetary period does not exceed the carbon budget'. The 'net UK carbon account' and the '1990 baseline' are defined terms which describe UK GHG emissions over, respectively, a particular time period, and in the year $1990 .{ }^{43}$ The 'carbon budget' is the amount set for the net UK carbon account in respect of each such period. ${ }^{44}$ As described in the introduction, these duties may well have wide legal influence. But, when considered independently, what is their effect? The effective legal enforceability of the primary duties can be challenged from two angles: First, the primary duties do not carry the absolute meaning that a literal reading would imply. Second, even if the primary duties are given their literal meaning, the courts should not enforce them. These two propositions are considered - and contested - in turn. ${ }^{45}$

\section{Taking the Primary duties literally}

Section 1(1) of the Act is 'concise and clearly drafted' ${ }^{46}$ It imposes a duty in unqualified language. ${ }^{47}$ As noted above, statutory interpretation routinely takes into account both literal and purposive meanings. However, in this case, the two align. A literal reading of section 1(1) might even be said to embody the Act's overall purpose. In spite of this, this 'plain meaning' interpretation has been contested.

a) A mere 'target duty'?

The strongest challenge to the primary duties being read as being 'absolute' was expressed by Christopher Forsyth, in his evidence to the Joint Committee:

\footnotetext{
43 ss 27 , s.1(2).

${ }^{44} \mathrm{~s} 4(1)(\mathrm{a})$.

${ }^{45}$ As should become clear, I do not mean to imply that a court would cleanly separate out these questions in the same way.

${ }^{46}$ Macrory (n 3) 307.

${ }^{47}$ One word in the primary duties does invite reflection: that the Secretary of State must 'ensure' the requisite fall in (GHG) emissions. However the use of this term is likely no more than a semantic admission that the Secretary of State cannot himself reduce GHG emissions. Only the 'cumulative conduct of a wide range of parties' can do so (Reid (n 41) 749). This conclusion is supported by the Explanatory notes to the Act which describe the duty as a 'duty to reduce'.
} 
[I]t is plain that [the s.1(1)] reduction is a target. ... Inherent in the idea of a target is an aspiration not a guarantee of achievement. At most then this clause can be interpreted as requiring the Secretary of State to use his or her best endeavours to achieve the target. ${ }^{48}$

A target duty is a category of duties in respect of which (though it is not express) "[t]he authority is simply required to "do its best" 49 and "failure ... without more does not constitute a justiciable breach' ${ }^{50}$ There are reasons to seriously doubt Professor Forsyth's conclusion that section 1(1) is a mere target. Primarily, it can be argued that the clear and unambiguous nature of the language simply speaks for itself: to 'downgrade' it in some way risks giving 'too little weight to the deliberate formulation of the duties'. ${ }^{51}$ Indeed, a similar criticism can be made of target duties more generally: 'there is a danger that [they] will devalue the notion of a duty and permit Parliament to reassure the public with empty gestures and the executive to sit back and take no further notice'. 52

Peter McMaster, in his contemporaneous analysis of the Act at the draft stage concluded of section 1(1): 'This is an unqualified duty to achieve a result, not an obligation merely to use best endeavours' ${ }^{53}$ Indeed, it would have been quite possible for the primary duties to incorporate the statutory language of 'best endeavours" ${ }^{\text {, }}$, or 'to such extent as he considers necessary'55 if that reflected Parliament's intention. The absence of such wording may be particularly significant given its appearance in other sections of the Act. ${ }^{56}$ Catherine Callaghan's authoritative analysis of target duties leads her to conclude that 'target duties are broadly framed ${ }^{57}$ But a comparison of the available examples of target duties ${ }^{58}$ with the primary duties in the Act shows that the latter are distinctly more clear and precise than any examples of the former. Target duties always incorporate qualified language: either language explicitly carving out an area of discretion; ${ }^{59}$ or imprecise or value-laden phrases which do

\footnotetext{
${ }^{48}$ Evidence to the Joint Committee (n 42) 238 (Evidence of Christopher Forsyth).

${ }^{49}$ Woolf and others (eds), de Smith's Judicial Review (6th edn, OUP 2007) 259, quoting R v Islington LBC ex parte Rixon [1997] ELR 66 [69].

${ }^{50}$ Catherine Callaghan, 'What is a "Target Duty”?' [2000] JR 184, 184.

${ }^{51}$ Reid (n 41) 753.

${ }^{52}$ Harry Woolf and others (eds), de Smith's Judicial Review (7th edn, OUP 2013) 282.

${ }^{53}$ Peter McMaster, 'Climate Change - Statutory Duty or Pious Hope' (2008) JEL 20(1) 115, 116.

54 eg National Audit Act 1983, s 6(5).

55 eg National Health Service Act 1977, s 3(1).

${ }^{56} \mathrm{eg}$, ss 2, 6, 21 ('if it appears to the Secretary of State that').

${ }^{57}$ Callaghan (n 50) 185.

58 Taken from Callaghan (n 50) 184-5; Woolf (n 49) 259; Auburn (n 26) 280.

${ }^{59}$ National Health Service Act 1977, s 3(1) ('to such extent as he considers necessary'); National Assistance Act 1948, s 29(1) ('to such extent as he may direct').
} 
not clearly define the breadth of the authority's discretion. ${ }^{60}$ The primary duties contain neither - so in my view they should not be considered as target duties.

Professor Forsyth also appears to be arguing from an alternative perspective. He acknowledges that the primary duties are 'broad, general duties' but he categorises them as target duties nonetheless - since 'a target is not something that you can guarantee, no one can guarantee you are going to hit the bull's eye, it is something you would like to happen but you are not sure it will'. ${ }^{61}$ The argument is that a duty which it may not be possible to fulfil should not be interpreted literally. Two responses can be made to this. First, Professor Forsyth may well be underestimating the capacity of the Secretary of State to fulfil this duty. Even if the 'policy levers' at the Secretary of State's disposal might constrain his ability to 'ensure' the necessary outcomes, ${ }^{62}$ it seems clear that a duty imposed on the Secretary of State is 'imposed upon government as a whole'. ${ }^{63}$ It is difficult to imagine that the wider Government will lack capacity to reduce GHG emissions by the requisite amounts: it will, after all, have control of all policy levers. It should also be noted that proposals and plans to enable carbon budgets to be met must first be prepared fully 11 years in advance of the beginning of a budgetary period. ${ }^{64}$ The system of carbon budgeting is designed to ensure long-term decisions are taken to chart a course which is realistic and achievable. Furthermore, the annual reports mandated by the Act - from the Secretary of State and the $\mathrm{CCC}^{65}$ - allow for regular policy and course adjustment. I would argue that the image of the Secretary of State aiming hopefully with a bow and arrow at some distant target is not apt. The Government as a whole will have been planning for many years how to achieve a result which is - as far as any result can be - within its extensive capacity to achieve. ${ }^{66}$

Secondly, it is not clear on what theoretical basis Professor Forsyth is making this argument. Coke CJ in Dr Bonham's Case (1610), ${ }^{67}$ stated: 'when an Act of Parliament is ... impossible to be performed, the common law will control it, and adjudge such act to be void'.

\footnotetext{
${ }^{60}$ Education Act 1996, s 14 ('sufficient schools'); National Assistance Act 1948, s 21 ('persons ... in need of care and attention'); Children Act 1989, s 17 ('promote the welfare of children ... who are in need'); Education Act 1944, s 41(1) ('adequate facilities'); Fire Services Act 1947, s 1(1) ('make provision for firefighting purposes'); National Health Service Act 2006, s 1(1) ('promotion of a comprehensive health service'); National Assistance Act 1948, s 29(1) ('promoting the welfare of...').

${ }^{61}$ Evidence to the Joint Committee (n 42$) 2$ (Evidence of Christopher Forsyth).

62 ibid.

${ }^{63}$ Friends of the Earth $v$ Secretary of State for Business Enterprise and Regulatory Reform [2008] EWHC 2518 (Admin) [36].

${ }^{64}$ This is the combined effect of ss 4(2)(b), 13(1), 14.

${ }^{65}$ ss $18,36,37$.

${ }^{66}$ We are, after all, talking about reducing GHG emissions - a logically straightforward (if politically challenging) task as compared, for example, with the targets to reduce child poverty pursuant to the Child Poverty Act 2010 (see Reid, n 41).

${ }^{67} 8$ Co Rep 114.
} 
However, such sentiments are now understood to be obsolete. ${ }^{68}$ While there may be exceptions to the classical formulation that "what Parliament at Westminster has enacted must always be obeyed by the courts', ${ }^{69}$ the difficulty of fulfilling such a duty is not one of them. ${ }^{70}$ As Collin $\mathrm{J}$ described in $R v$ Newham 'Parliament has imposed the duties but the authorities do not have the resources to fulfil them. Nevertheless, I must apply the law Parliament has enacted however hard that may be for the authority in question' ${ }^{71}$

b) A new kind of duty: outcome duties

Rather than being shoe-horned into an (ill-fitting) pre-existing category - of target duties hard-edged and time-limited duties like those in the Act should be understood as a recent legislative innovation which require a fresh assessment. ${ }^{72}$ As Maurice Kay LJ acknowledged: ' $[\mathrm{t}]$ his style of legislation is of recent origin (...) [o]n any view, this is a rapidly developing area of public law with an obvious and concerning potential for litigation' ${ }^{73}$ The case in question concerned the meaning of a statutory provision which sets a specific deadline for a duty to be fulfilled. ${ }^{74}$ Although it also contains qualifying language ('as far as reasonably practicable'), the presence of a specific deadline was enough to distinguish the duty from a target duty. ${ }^{75}$

The Act's primary duties are a further step removed from target duties. Colin Reid identifies a new, albeit (so far) uncommon, kind of time-limited duty which contains no qualifying terms whatever. ${ }^{76}$ He terms such duties 'outcome duties', and the Climate Change Act is his leading example. Outcome duties, he argues:

can be taken at face value as creating a new form of statutory duty, representing a legal innovation through the imposition of unqualified legal duties on Ministers to achieve certain outcomes which can be met only as the result of a complex

\footnotetext{
${ }^{68}$ David Feldman (ed), English Public Law (OUP 2004) 134-135.

69 ibid 128.

${ }^{70}$ Feldman (n 68) 127-154 considers the following such exceptions: limitations on Parliament binding its successors and the effects of international law, the Human Rights Act 1998, and the European Communities Act 1972. The judicial limits of Parliamentary supremacy today are typically identified in terms of Parliament seeking to over-ride fundamental rights or subvert the rule of law (see eg Baroness Hale in $R$ (Jackson) $v$ Attorney General [2006] 1 AC (HL) [159]).

${ }^{71} R v$ Newham London Borough Council (2001) 33 HLR (HC) 29, [17] (emphasis added).

${ }^{72}$ Reid (n 41); Annabelle Lee and Justin Leslie, 'Judicial Review of Target-setting Legislation' [2010] 15 Judicial Review 236.

${ }^{73} R$ (Friends of the Earth) $v$ Secretary of State for Energy and Climate Change [2009] EWCA Civ 810 [2], [19]

${ }^{74}$ Warm Homes and Energy Conservation Act 2000, s 2.

${ }^{75}$ Lee and Leslie (n 72) [9].

${ }^{76}$ Reid also identifies the Child Poverty Act as containing outcome duties. However, since his article (n 41) was written, the Energy Act 2013 has joined this select group.
} 
aggregation of legislation, decisions, actions and public spending over an extended period. ${ }^{77}$

There is, however, one final potential obstacle to the primary duties being understood as outcome duties: the fact that in 'determining which claims to uphold on the merits, courts will almost irresistibly tend to peek ahead at the remedial consequences and weigh their acceptability'. ${ }^{78}$ As discussed in the following sections, the remedial consequences of enforcing a breach of a primary duty may be severe - so this could tempt a court to deny a claim on its merits. However this could only be achieved by 'downgrading' the outcome duties ${ }^{79}$ in the face of the kind of arguments made above which caution against it. ${ }^{80}$ Instead, the appropriate response, as explored further in Section D, must be to mould the remedial consequences such that they are acceptable so that the duties can be given their proper effect as outcome duties. In what follows I assume that the Act's primary duties will be treated as outcome duties - and I argue that they can and should be effectively enforced.

\section{Contesting the consensus against enforceability}

The starting point in this scenario must be that courts will in general be predisposed to seeing that duties are effectively enforced. ${ }^{81}$ Indeed, 'ensur[ing] that a public body complies with the law' may be described as the 'essential nature' of public law proceedings. ${ }^{82}$ The novelty of outcome duties may require that '[d]ifferent paths have to be explored" ${ }^{83}$ in order that they are given their proper effect. Specifically, such duties '[shift] the burden for the accountability for important parts of government policy onto the courts ${ }^{\text {}} 84$ and therefore 'there is a strong argument for the amplification of the courts' role to ensure that there is no

\footnotetext{
${ }^{77}$ Reid (n 41) 766.

${ }^{78}$ Richard Fallon, 'The linkage between justiciability and remedies - and their connections to substantive rights' (2006) 92 Virginia LR 634, 642. The more widely acknowledged example of overspill is the influence of the merits stage on the preliminary stage, as established in $R v$ IRC ex parte National Federation of Self-Employed and Small Businesses Limited [1982] AC 617.

${ }^{79}$ This is because, as noted in the following section, if the duties are taken to be outcome duties, the success of the claim on its merits follows almost automatically.

${ }^{80}$ This particular effect was identified in an earlier analysis of why certain duties were treated as target duties and not specific duties (specific duties having obvious parallels to outcome duties): 'the artificial distinction between target and specific duties stems from the judiciary's anxiety over the resource implications of their judgments': L Clements, Community Care and the Law (3rd edn, Legal Action Group 2004) 11-13, quoted in Jeff King, 'The Justiciability of Resource Allocation' [2007] 70(2) MLR 197, 214.

${ }^{81}$ HWR Wade and CF Forsyth, Administrative Law (9th edn, OUP 2004) 589-590. Once duties are 'sufficiently specific', 'the courts do not shrink from enforcing them'. (However, this may not always be the case: King (n 81)).

${ }^{82}$ Land Securities Plc v Fladgate Fielder [2009] EWCA Civ 1402 [94].

${ }^{83}$ Reid (n 41) 753.

${ }^{84}$ Lee and Leslie (n 72) 240. The discussion is of target-setting legislation - outcome duties form a subset of this.
} 
[resulting] gap in accountability' ${ }^{85}$ The courts should not feel reluctant to adapt to this new type of statutory provision, including by taking on an amplified role if appropriate. For common law constitutionalists, 'evolution' and 'experiment' are fundamental parts of the common law's 'ethos'. ${ }^{86}$ Indeed, for those who believe that the courts 'ought to be recognized as the best existing forum for moral/political deliberation ${ }^{87}$ it will be natural that those courts take up the baton of political accountability. Ultra vires proponents will in general favour a more circumscribed judicial role since 'the methodology of ultra vires confines the judicial function to the implementation of Parliament's will ${ }^{18}$ in a way which the common law model does not. However, even on this basis, there can surely be no more legitimate foundation for an innovative judicial response than an innovative expression of Parliament's will - as is found in these outcome duties.

In spite of the persuasive arguments of principle that favour the courts adopting an amplified role in response to the Act, Aileen McHarg has identified a consensus that s.1(1) will not be meaningfully enforced. Her description provides a useful basis for the discussion that follows:

The consensus is that the courts are extremely unlikely to award anything other than declaratory relief, since this would involve them in complex and polycentric issues of policy prioritization and resource allocation which are typically regarded as nonjusticiable. If judicial review is sought before the target/budget date has passed, the action might be regarded as premature; if it is brought afterwards, it might be seen as purely academic $(\ldots)^{89}$

McHarg's objections on the basis of non-justiciability are considered at a) - c); those on the basis of timing are dealt with at d).

a) Non-justiciability

In respect of non-justiciability, McHarg appears to represent the consensus view. In their analyses of the Act, both Reid and Mark Stallworthy echo the reasons she gives for the nonjusticiability of the primary duties. ${ }^{90}$ However, in my view, their arguments are problematic.

\footnotetext{
85 ibid.

${ }^{86}$ John Laws, The Common Law Constitution, (CUP 2014) 7. They are two aspects of the common law's 'fourfold ethos'; the others being 'history and distillation'.

${ }^{87}$ Thomas Poole, 'Back to the Future? Unearthing the Theory of Common Law Constitutionalism' (2003) OJLS 23(3) 435, 442.

${ }^{88}$ Mark Elliott, 'The ultra vires doctrine in a constitutional setting: still the central principle of administrative law' (1999) CLJ 58(1) 129, 131 (emphasis added).

${ }^{89}$ McHarg (n 9) 477-8.

${ }^{90}$ Reid (n 41) 754-5; Mark Stallworthy, 'Prospects for the UK's national approach to climate law-making?' in Marjan Peeters and others (eds) Climate Law in EU Member States (Elgar 2012) 113, 129.
} 
In what follows, I argue that in many respects the elements of non-justiciability they cite policy prioritisation, polycentricity, complexity, and resource allocation - do not convincingly apply. This is because such elements are traditionally or primarily focused upon the 'merits' stage of a case; specifically on the 'inputs' to a case. Yet in a case to enforce the Act's primary duties, the merits stage does not exhibit these elements. As McHarg appears to suggest, the real obstacle to effective enforcement of the primary duties is the lack of effective and unintrusive remedies, however it is not clear to what extent (if at all) arguments about non-justiciability operate at this stage.

Two characteristics of a judicial review claim in respect of an alleged breach of the Act's primary duties combine to make it 'bottom-heavy': an unusually simple merits stage and an unusually complex and contentious remedies stage. ${ }^{91}$ The merits stage of such a case ie where the substantive questions of law are determined - should, if considered in isolation, ${ }^{92}$ be straightforward. The only substantive legal reasoning relates to whether a primary duty should be treated as an outcome duty. I have argued above that it should be. If so, there is no further legal test to be applied: the Secretary of State will already have announced the breach of a primary duty to Parliament by the time a judicial review claim to enforce a primary duty is brought. ${ }^{93}$ The court will have its answer before it: either the net UK carbon account exceeds the carbon budget in question or it does not. Arriving at such a judgment will not involve complex, polycentric, or policy questions (however defined), nor will it go to the allocation of resources.

By contrast, at the remedies stage the questions facing the court will be unusually challenging. This is in large part because a statutory duty is in question, not a statutory power. As Purdue noted in his review of one of the few thorough studies into public law duties: ${ }^{94}$

[T] he emphasis of the law on public duties is on their positive enforcement, which is why the topic is usually associated with the remedy of mandamus. And it is in the enforcement of public duties that the courts get closest to usurping the task of the administration. ${ }^{95}$

\footnotetext{
${ }^{91}$ I take the judicial review process to comprise three stages, which I refer to as the 'preliminary', 'merits' and 'remedies' stages, following, eg: Fallon (n 78) 705 (the terms used there are: 'justiciable', 'substantive' and 'remedial'); Carol Harlow and Richard Rawlings, Law and Administration (3rd edn, CUP 2009) 672-7 use the terms 'permission', 'grounds' and 'remedies'.

92 They might not be considered strictly in isolation: text to (n 78).

93 s 18.

94 The study in question is: Andrew J Harding, Public Duties and Public Law (Clarendon Press, 1989).

${ }^{95}$ HM Purdue, 'Publication Review - Public duties and public law AJ Harding' [1989] PL 500, 501.
} 
The contrast is with remedying an action taken in excess of a decision-maker's powers, something that can usually be undone by the making of a simple quashing order. ${ }^{96}$ The courts will come all the closer to 'usurping the task of the administration' where the duty being enforced is an outcome duty. This is because such duties 'can be met only as the result of a complex aggregation of legislation, decisions, actions and public spending over an extended period'. ${ }^{97}$ If a court's ordering a civil servant to make a particular order, or even make housing or other public resources available, ${ }^{98}$ might be unduly intrusive, how can resolving a breach of the UK's long-term decarbonisation target even be contemplated? Here we see what look like the hallmarks of non-justiciability but, as the following section argues, it is doubtful whether such elements of non-justiciability have any theoretical relevance when applied at the remedial stage.

Whereas the shape of a claim in respect of the primary duties is 'bottom heavy', I argue in what follows that non-justiciability - specifically the elements considered here ${ }^{99}-$ is a decidedly 'top-heavy' doctrine. It asks questions primarily of the merits stage of a claim which, as we have seen, does not, where outcome duties are at issue, involve difficult questions. By contrast, non-justiciability says little about remedies, yet it is at this stage that the challenge of enforcing the primary duties is felt. This misalignment undermines any simple 'diagnosis' of non-justiciability and muddies an analysis of the real obstacles to enforcement.

To be clear, non-justiciability is used here in the 'secondary justiciability' 100 or 'judicial restraint ${ }^{\text {' }}{ }^{101}$ sense. It describes how, 'in some sensitive cases', the 'general principles of judicial review' are not applied 'with full rigour'. ${ }^{102}$ (The distinct question of 'jurisdiction ... to hear a case' applies at the preliminary stage, and incorporates questions of standing and timing, ${ }^{103}$ considered elsewhere. ${ }^{104}$ ) While acknowledging the theoretical objections that

\footnotetext{
${ }^{96}$ Feldman (n 68) 923-4.

${ }^{97}$ Reid (n 41) 766.

${ }_{98}$ Example taken from Harding (n 96) 29-30.

${ }^{99}$ It is possible that alternative formulations of non-justiciability could account more convincingly for the challenges inherent in enforcing the Act's primary duties. These might include inter alia inter-institutional comity and collaboration (King (n 22) 139).

${ }^{100}$ To be distinguished from primary justiciability - ie the categories of decision which are inherently unreviewable' (Woolf (n 49) 15) - which is not relevant to the current discussion: none of the powers which Lord Roskill identified in GHCQ ([1985] AC 374, [418]) as not being 'susceptible to judicial review' are at issue here, and the breadth of such categories has diminished ever since (Woolf (n 52) 124).

${ }^{101}$ Jeff King, 'Institutional Approaches to Judicial Restraint' [2008] 28(3) OJLS 409, 420: 'The justiciability question', framed in these terms, 'asks ... essentially the same or very similar question to [those asked by] institutional approaches [to judicial restraint]'.

${ }^{102}$ Paul Daly, 'Justiciability and the "Political Question" Doctrine [2010] PL 160, 161.

103 ibid 160-161.

${ }^{104}$ Standing is discussed in the text to (n 41). Timing is considered at d), below.
} 
might be made, the separate elements of non-justriciability cited by McHarg and others are now considered in turn. ${ }^{105}$

Policy prioritisation: The distinction between principle and policy is a formalist division of legal matters into those that courts should and should not adjudicate on. ${ }^{106}$ It has been criticised, for, inter alia, offering a 'false pretence to objectivity' and 'disguis[ing]' the real reasons for judicial restraint. ${ }^{107}$ For Lord Steyn, the dividing line did not even exist in principle. ${ }^{108}$ Nonetheless, the distinction continues to be utilised by the courts. ${ }^{109} \mathrm{~A}$ brief examination of leading cases in which the presence of policy considerations has cautioned against judicial intervention shows the following: it is the decision which the court is reviewing whose 'policy nature' leads to a finding of non-justiciability. ${ }^{110}$ In other words, this element of non-justiciability is operating on the 'inputs' to a case: at the merits, not the remedies, stage.

Polycentricity: '[A] polycentric problem is one that comprises a large and complicated web of interdependent relationships, such that a change to one factor produces an incalculable series of changes to other factors'. ${ }^{111}$ Polycentric disputes are, according to Lon Fuller's thesis, unsuitable for adjudication because of unexpected or complex repercussions. ${ }^{112}$ In spite of this explicit concern for the effect (the repercussions) of a judgment, it seems clear that even polycentricity is an element of non-justiciability which primarily asks questions of the action being reviewed by the court, or even on who took that action, ${ }^{113}$ rather than the nature of the remedy. Fuller's leading example of a polycentric case - in which a court would be reluctant to intervene - is one involving the review of a (polycentric) decision to set a

\footnotetext{
105 Specifically, attempting to 'isolate' individual elements of non-justiciability might be criticised on the grounds that it assumes these elements are conceptually detachable from the judicial process, when arguably they are 'internal to ordinary legal analysis': TRS Allan, 'Judicial deference and judicial review: legal doctrine and legal theory' (2011) 127 LQR 96, 116. Indeed, the non-doctrinal approach is 'probably the best description of how most courts operate': King (n 101) 411.

${ }^{106}$ King (n 101) 416.

107 ibid 414.

${ }^{108}$ Lord Steyn: 'Deference: A Tangled Story', 2004 Judicial Studies Board Lecture, 25 November 2004: 'it is an everyday occurrence for courts to consider, together with principled arguments, the balance sheet of policy advantages and disadvantages'.

${ }^{109}$ King (n 101) 416: 'criticism of this idea is so deep and trenchant that one could be forgiven for thinking another round is unnecessary. But as the decided cases show, it still is'.

${ }^{110}$ Michael Fordham, Judicial Review Handbook (6th edn, Hart Publishing 2012) 150: listed are eight leading examples of 'Politics/Policy-laden Decisions'. Together they point clearly towards this conclusion. Typical is $R$ (Milton Keynes Council) v Secretary of State for Communities and Local Government [2011] EWCA Civ 1575 [26]: 'the court must take special care ... not to pass judgment on action which is essentially political'.

111 Jeff King, 'The pervasiveness of polycentricity' [2008] PL 101, 101-102, quoting Lon Fuller, 'The Forms and Limits of Adjudication' (1978-1979) 92 Harv L Rev 353.

112 ibid.

${ }^{113}$ Woolf (n 52) 26: A polycentric matter is one 'where the decision-taker has broad discretion involving policy and public interest considerations'.
} 
wage scale applicable to many thousands of public servants. ${ }^{114}$ Although such a review would indeed have wide-ranging consequences, it does not appear to be the consequences per se which lead to a 'finding' of non-justiciability.

Jeff King has proposed a refinement of polycentricity which suggests that remedies may to some extent be taken into account. On this account, 'remedial flexibility' is one of numerous 'attenuating factors' which 'will help sculpt the legal issues such that the degree of polycentricity is manageable'. ${ }^{115}$ In other words, the available remedies will not on their own render a matter justiciable or non-justiciable, however it may be possible to make what would have been a non-justiciable matter into a justiciable one by choosing a remedy which softens the unwelcome polycentric effects of an adjudication. This still represents a minor role for remedies. It should also be noted that this account appears to push only in the direction of expanding justiciability; it does not explain how the available remedies could render a claim non-justiciable.

A related consideration is stare decisis, the potential repercussions of which may also be relevant to a finding of non-justiciability: John Allison cites an instance where 'the Law Lords [considered that they] ought not to develop the law in complex disputes where it would be impracticable to foresee all the consequences of tampering with it'. ${ }^{116}$ However, the development of the law takes place at the merits stage. Stare decisis is largely oblivious to remedies. ${ }^{117}$

Complexity: The idea of complexity clearly has links with polycentricity, ${ }^{118}$ however the two will not necessarily go together. As King describes it, complexity may be a description of the kind of subject-matter which makes a case polycentric; it aligns with 'areas' of decisionmaking in a way that polycentricity does not. ${ }^{119}$ Examples of complexity in this context include the adjudication of certain complex scientific questions - ie the review of something 'understood with great difficulty' ${ }^{120}$ - and, similarly, the review of 'complex economic issues'. ${ }^{121}$ Remedies do not seem to be relevant.

\footnotetext{
${ }^{114}$ Quoted, eg, by King (n 111) 102.

115 King (n 22) 209-210.

116 John Allison, 'The procedural reason for judicial restraint', [1994] PL 452, 542, quoting Steadman v Steadman [1976] AC 536 [542] (emphasis added).

${ }^{117}$ However, there are certain constraints on the remedies which a court may order, and past cases may have some influence: Thomas Bingham, 'Should public law remedies be discretionary?' (1991) PL 64.

${ }_{118}$ Note, eg text to (n 116).

${ }^{119}$ King (n 22) 191: 'many feel that polycentricity is foremost about complex subject-matter. But something can be complex without being polycentric'; King (n 22) 193-194: 'In law, we ought to regard polycentricity as a property of issues or problems and not 'areas' of decision-making such as resource allocation ...'

${ }^{120}$ King (n 22) 191.

${ }^{121}$ Fordham (n 110) 150.
} 
Resource Allocation: Here again the connections between different elements of nonjusticiability are apparent. As Paul Daly represents it, the non-justiciability of 'the allocation of scarce resources' is an application of the courts' 'traditional' concerns about complexity, as well as institutional legitimacy. ${ }^{122}$ Both King and de Smith's Judicial Review note the close connection between polycentricity and resource allocation; the latter tending to form a sample set of the former. ${ }^{123}$ On this analysis, the consideration of resource allocation adds little to the discussion.

King adds nuance, by drawing a distinction between two types of case concerned with resource allocation. First, there are cases where the courts are reviewing the exercise of a power to allocate public resources. ${ }^{124}$ These cases, identified according to the nature of the 'input' to a case, will be non-justiciable. ${ }^{125}$ On the other hand are cases concerned with 'allocative impact': 'the financial or distributional adjustment made necessary by a court's judgment ${ }^{\prime}{ }^{126}$ Allocative impact can therefore be a function of the particular remedies ordered in a case (as well, potentially, as the effect of the substantive finding of law). However, King concludes that the presence of allocative impact does not constitute a stand-alone element of non-justiciability. ${ }^{127}$ Again, we must conclude that this element of non-justiciability resource allocation - operates at the merits stage of a case but does not do so to any appreciable extent at the remedies stage.

\section{b) Justiciable primary duties...}

It should not be surprising that doctrines of non-justiciability have the shape that they do given that they have developed in the context of administrative law's focus on powers rather than duties. Just as claims to enforce powers tend to be naturally 'top-heavy' (intense scrutiny of administrative action at the merits stage; relatively straightforward remedies stage) so the doctrines which structure these claims - such as non-justiciability - take a similar shape. The expansion of public law duties and therefore the expansion of claims which are 'bottomheavy' may, in the coming years, demand a change of judicial perspective.

\footnotetext{
122 Daly (n 102) 173-174.

${ }^{123}$ King (n 111) 101: ' $\ldots$ the argument that polycentric issues are non-justiciable is most frequently raised in the context of resource allocation disputes'; also King (n 22) 193-194; Woolf and others de Smith's (7th edn) (n 52) 26: 'Most ... decisions involving the distribution of limited resources ... fall into the category of polycentric decisions'.

${ }^{124}$ King (n 80) 198 (cases described as involving 'discretionary allocative decision-making').

125 ibid 197-8.

126 ibid 197 (emphasis added).

${ }^{127}$ It is 'by itself no bar to justiciability': King (n 80) 209.
} 
However, whether it is a product of neglect or design, the apparent fact that nonjusticiability does not operate at the remedies stage of a case ${ }^{128}$ has significant implications for the Act's primary duties. Since enforcement of the primary duties does not raise questions of non-justiciability at the merits stage, it follows that, contrary to the consensus identified by McHarg, ${ }^{129}$ the primary duties are not non-justiciable.

If the primary duties are justiciable, this does not, of course, guarantee the outcome of a claim to enforce them. However, it does mean that, in such a claim, a court should not resile from applying the general principles of review with 'full rigour'. ${ }^{130}$ On my account, a court in doing so should treat the primary duties as outcome duties, and, it then follows, vindicate the claim on its merits. It is also argued above that a court should feel entitled (if not obliged) to take on an amplified role in enforcing the primary duties, and this must extend to seeking to provide a genuinely effective remedy. ${ }^{131}$ How a court might do so is explored in detail in Section D, below.

c) ...or Non-justiciable remedies

An alternative conclusion is that a court, faced with a claim to enforce a primary duty, would nonetheless find it to be non-justiciable. It might seek to do so on the basis of there being an element of 'overspill' (so far little acknowledged ${ }^{132}$ ) by which the presence of elements of non-justiciability could in fact be informed by the nature of the available remedies. In other words, a claim might be found to be non-justiciable on the basis of a likely remedy appearing to be (for example) polycentric or complex in character. Indeed, there is commentary by Richard Fallon which posits 'a broad linkage between the entire set of justiciability doctrines - including standing, mootness, ripeness, political question, and so forth - and judgments concerning necessary, appropriate, and acceptable judicial remedies' ${ }^{133}$ In particular, Fallon asserts that remedies 'exert a nearly ubiquitous, often unrecognized, and little understood

\footnotetext{
${ }^{128}$ With the possible and partial exception of 'polycentricity'.

${ }^{129}$ The contrasting framework of analysis underpinning the consensus position is apparent where Stallworthy notes that the Act's primary duties may be difficult to enforce because 'the courts are generally loathe to interfere with decisions' (emphasis added) exhibiting the elements of non-justiciability discussed here (Stallworthy (n 90) 129).

${ }_{130}$ Returning to Daly's formulation of secondary justiciability (n 102).

${ }^{131}$ A court might not feel entitled to deny relief following success at the merits stage: Bingham (n 117).

${ }^{132}$ At least not explicitly. It may be that in considering non-justiciability to be a barrier to enforcing the primary duties, McHarg and others are (consciously or otherwise) assuming that non-justiciability operates at the remedies stage. This would accord with Fallon's view. However, see Stallworthy (n 129) which suggests otherwise.

${ }^{133}$ Fallon (n 78) 635.
} 
influence in the shaping and application of justiciability doctrines'. ${ }^{134}$ This idea forms part of a broader thesis ${ }^{135}$ which holds that the courts should acknowledge the interconnectedness between the justiciability doctrines that operate at all stages of a claim and seek an 'optimal balance among them'. ${ }^{136}$

Viewed through this lens, questions of complexity, polycentricity, or considerations of policy prioritisation or resource allocation, whether they arise at the remedies stage or the merits stage, may (rightly, according to Fallon) influence the court's overall approach to resolving the case before it. In the face of these complexities, the temptation to retreat into non-doctrinalism should be resisted. ${ }^{137}$ Seeking to acknowledge and elucidate the connections and overspills between the stages of a claim has the advantage of bringing the "considerations conditioning restraint ... in[to] full view, ${ }^{138}$ the value of which, it is hoped, can be seen in the present discussion. If the apparent obstacles to the effective enforcement of the Act's primary duties can be demystified, the way can be made clearer for their being overcome.

Indeed, the central obstacle can now be seen: it is not the 'non-justiciability' (as traditionally understood $)^{139}$ of the primary duties, but the difficulty of finding an appropriate remedy. ${ }^{140}$ If a remedy can be found which is more appropriate - or, following Fallon's analysis, more 'justiciable' - that obstacle falls away.

\section{d) Overcoming jurisdictional objections}

Before proceeding to consider remedies, it is necessary to address McHarg's concerns regarding the timing of a claim, ${ }^{141}$ both in terms of prematurity ('ripeness') and lateness ('mootness'). ${ }^{142}$

Ripeness: A claim brought before the end of a budgetary period to enforce a breach of a primary duty would not necessarily be regarded as premature. ${ }^{143}$ This is because the duties

\footnotetext{
${ }^{134}$ ibid 636. This is his 'Remedial Influences on Justiciability Thesis'. This may imply that the shape of nonjusticiability (ie its apparent inapplicability to remedies) is indeed more a consequence of neglect than design; see text to (n 128).

135 Termed the 'Equilibration Thesis'.

${ }^{136}$ Fallon (n 78) 705.

${ }^{137}$ Non-doctrinalism means accepting that 'the scope for deference [an idea closely related to non-justiciability] is a matter so highly attuned to all the detailed circumstances of the particular case that any attempt to give it specific, independent doctrinal form is bound to fail': Allan (n 105) 99.

${ }^{138}$ King (n 80) 412.

139 ie operating at the merits stage of claim.

${ }^{140}$ This problem of remedies may take effect through: (a) non-justiciability being 'identified' at the remedies stage (following Fallon) and the available remedies being considered non-justiciable; (b) a primary duty being treated as a target duty: see text to (n 80); or (c) a claim which was successful at the merits stage being denied an effective remedy (if a court felt entitled to take this route: (n 131)).

${ }^{141}$ Text to (n 89) (second sentence).

142 Following Daly's terminology (n 102).

${ }^{143}$ If it were treated as a target duty, not an outcome duty, the required duty of 'best endeavours' would operate continuously so different considerations would apply. (Space precludes a discussion of whether the primary
} 
are defined in terms of 'the net UK carbon account'; ${ }^{144}$ a total permissible quantity of GHG emissions, which could in principle be exceeded before a budgetary period ended. ${ }^{145}$ Even if the net UK carbon account had not yet been exceeded, a court could entertain a judicial review claim if this appeared inevitable ${ }^{146}$ or if the Government conceded that it would be exceeded in due course. ${ }^{147}$

Mootness: Mootness is more likely to be a relevant concern in an action to enforce a primary duty. A judicial review claim must be filed 'promptly; and (...) in any event not later than three months after the grounds to make the case first arose', ${ }^{148}$ yet it will typically not be established by this time whether a breach has occurred. The basis of any such claim - the net UK carbon account - need only be published by the Secretary of State 17 months after the end of the relevant budgetary period. ${ }^{149}$ This is potentially problematic. However, the House of Lords in Anufrijeva described the rules on mootness as 'simply an application of the right of access to justice', 'a fundamental and constitutional principle of our legal system'. ${ }^{150}$ Rigidly applying the (already uncertain ${ }^{151}$ ) rules in the above circumstances would be to deny the right of access to justice and therefore offend the rules in principle.

There are good reasons to think that the publication of the net UK carbon account should signal the start of the '3-month clock'. First, this might be analogous to 'notice of a decision'; ruled in Anufrijeva to be when the case first arose. ${ }^{152}$ Second, since a primary duty will be breached by the effect of cumulative (in)action, it is hard to imagine what other point in time could be taken as the start point. Lastly, the breach itself would arguably only occur when the net UK carbon account 'came into existence' - presumably by its being made publicly available after the end of the budgetary period. Indeed, until it is published, the Government is able to make adjustments to the carbon account; ${ }^{153}$ potentially making good

\footnotetext{
duties might have a dual character, behaving like target duties where claims are brought during a budgetary period, and as outcome duties otherwise.)

144 s 27.

${ }^{145}$ In practice, there may be difficulties. For example, this would require the availability of reliable emissions figures prior to the end of the relevant period. It would also be subject to the arguments made in the following section, eg text to (n 153).

${ }^{146} \mathrm{eg}$ if annual data showed a significant and/or widening gap between actual emissions (s 16) and indicative projected emissions required to meet a carbon budget (s 12).

147 This was the case in Friends of the Earth (n 68) [9].

${ }^{148}$ Civil Procedure Rule 54.5(1). These two requirements operate independently, so the three month time limit functions as a 'long-stop': Jamie Potter and Dervla Simm, 'Timing is Everything: When Should a Claimant Bring a Judicial Review Claim?' [2013] JR 421.

${ }^{149}$ s 18(9); s 20(7) for 2050.

${ }^{150} R$ (Anufrijeva) $v$ SoS for the Home Department [2003] UKHL 36 [26].

${ }^{151}$ Potter and Simm (n 148) 421.

${ }^{152}$ Anufrijeva (n 150) [26].

${ }^{153}$ ss 17(1),(5). Note also that s 21(3) allows for the amendment of a carbon budget during a budgetary period.
} 
what would otherwise constitute a breach. Whether or not, as McHarg suggests, a claim made after the end of a budgetary period might be 'purely academic' will depend upon the remedies that a court is able to order; discussed in the following section.

\section{FINDING AN EFFECTIVE REMEDY}

In 1973, Lord Denning said: 'We live in an age when Parliament has placed statutory duties on government departments and public authorities - for the benefit of the public - but has provided no remedy for the breach of them'. ${ }^{154}$ Since then, remedies have failed to expand to fill the role required of them, ${ }^{155}$ something underlined now by the advent of outcome duties. As argued above, it is the unavailability of an effective and appropriate remedy which represents the primary challenge for the enforcement of the Act's primary duties. There is also, as noted, 'a strong argument for the amplification of the courts' role' to ensure that the primary duties are appropriately enforced, ${ }^{156}$ which must involve forging an acceptable and effective remedy.

\section{Remedies under the Act}

It is first necessary to address those arguments which hold that the courts should refrain from ordering effective remedies in this context. Perhaps the most common basis for this view is that, since the Act requires the Secretary of State to report GHG emissions to Parliament following the end of each budgetary period, ${ }^{157}$ the intention must have been that he would be accountable politically rather than through the courts. ${ }^{158} \mathrm{~A}$ general response is that, as Lord Diplock stated in the $I R C$ case, '[departments of central government] are responsible to a court of justice for the lawfulness of what they do, and of that the court is the only judge'. ${ }^{159}$ More specifically, the Government in the course of the Act's pre-legislative scrutiny explicitly denied that political accountability was intended to oust legal accountability. ${ }^{160}$ Arguably, a judicial remedy should not be awarded where a political remedy would be as 'convenient, beneficial and effective'. ${ }^{161}$ By this measure, however, a statement to Parliament would fall far short of any substantive remedy. A declaration might be comparable in these terms; however, such a remedy should be avoided for the reasons given below.

\footnotetext{
${ }^{154}$ Attorney-General, ex rel McWhirter v Independent Broadcasting Authority [1973] QB 626 [646].

${ }^{155}$ Harlow and Rawlings (n 91) 672.

${ }^{156}$ Lee and Leslie (n 72) 240.

${ }^{157}$ s 18 ; s 20 for 2050.

${ }^{158}$ See eg Macrory (n 3) 309; McHarg (n 19) 479-480.

${ }^{159}$ IRC (n 78) [619].

160 DEFRA (n 7) 23.

${ }^{161}$ Harding (n 94) 106. This test is now seriously doubted: Bingham (n 117) 72.
} 
The courts should not be discouraged by the lack of 'hard-edged' compliance procedures in the Act, which might ordinarily 'lead to an exceptional reluctance to fashion corrective remedies'. ${ }^{162}$ On the Government's account, calls for such procedures ${ }^{163}$ were rejected because they might have interfered with an effective judicial response: 'attempting to set out specific sanctions carries a risk that whatever sanction was specified might be less stringent than one which could be prescribed by a court of law'. ${ }^{164}$ Similarly, the then Secretary of State, David Miliband MP highlighted the need for the Act to reserve for judges 'maximum flexibility' to order 'appropriate sanctions', and the value of thereby creating an 'additional fear' among ministers. ${ }^{165}$ The status of evidence given by Government in prelegislative scrutiny is generally far from settled. ${ }^{166}$ While in general Parliamentary material should not be used to aid statutory construction, ${ }^{167}$ Government statements of the kind quoted, if they have any effect at all, should embolden a court to consider fashioning innovative and 'stringent' corrective remedies.

Finally, there is a risk that a court might order a mere declaration - that a Secretary of State had breached a primary duty - as a remedy. However, doing so would 'add nothing to the reporting provisions already in the $[\mathrm{Act}]^{168}$ and it would risk giving the same impression as awarding no remedy at all; namely that the court was impotent ... [since giving a] judgment not accompanied by an effectual remedy would risk that appearance' ${ }^{169}$ For these reasons a declaration should be avoided.

\section{The court's remedies}

A failure to perform a duty will generally be most effectively remedied by a positive injunction or a mandatory order; the former probably being preferred on account of the greater flexibility it would afford. ${ }^{170}$ It should be noted that there is no absolute rule against either being ordered directly against the Secretary of State. ${ }^{171}$ But what form of either kind of remedy a court might order is a matter of some speculation. A number of possible remedies have been suggested, some more realistic than others. These include:

\footnotetext{
162 McMaster (n 53) 118.

163 DEFRA (n 7) 53.

${ }^{164}$ DEFRA (n 7) 23 (emphasis added).

${ }^{165}$ Evidence to the Joint Committee (n 42) 149-150 (Evidence of David Miliband MP).

${ }^{166}$ Elisabeth Laing, 'Pepper v Hart: Where Are We, How Did We Get Here, and Where Are We Going?' [2006] JR 44

167 The exception to the rule originated in Pepper $v$ Hart [1993] AC 593. For the exception to apply, there must be a specific statutory provision which is 'ambiguous or obscure or [leads] to absurdity' [594].

${ }^{168}$ McMaster (n 53) 116. (He is referring to ss 18, 20).

${ }^{169}$ Fallon (n 78) 670.

${ }^{170}$ Feldman (n 68) 926.

${ }^{171}$ Woolf and others (n 49) 888.
} 
i) Ordering the Government 'to purchase emissions credits on the open market' to reduce the net UK carbon account. ${ }^{172}$

ii) Ordering the Government to invest in appropriate infrastructure an amount of money equivalent to the cost of purchasing such emissions credits, in order to allow future budgets to be met. ${ }^{173}$

iii) Ordering that 'the excess emissions [be] deducted from the carbon budget for the subsequent period'. ${ }^{174}$

iv) Ordering financial penalties against the Government. ${ }^{175}$

v) Compensating persons harmed by the breach. ${ }^{176}$

vi) Imposing criminal sanctions against the Secretary of State. ${ }^{177}$

vii) Imposing a '40 seat penalty' for the Governing party at the following General Election. ${ }^{178}$

viii) 'Loss of the office of Prime Minister'. ${ }^{179}$

The first suggestion is perhaps the most commonly cited. This would come closest to an enforcement of the duty in literal terms, by retrospectively adjusting the net UK carbon account. It would, however, do little more than relax the constraints on the use of emissions credits prescribed by the Act. ${ }^{180}$ And, as with any financial penalty against the Government (see also proposal iv), it might be argued simply that the 'taxpayer was being punished'181 (though here, at least, overall GHG emissions would be limited ${ }^{182}$ ). The third proposal again constitutes an effective relaxation of limits imposed by the Act - in this case on how much excess emissions are allowed to be allocated to the subsequent budgetary period. ${ }^{183}$ While this remedy might be justifiable in certain circumstances, it does little more than kick the problem further down the road. This remedy could be used repeatedly without bringing about any substantive change in emissions. McMaster has noted that any award of compensation (proposal v) would be profoundly hindered by problems of causation even if a duty was

\footnotetext{
172 McMaster (n 53) 119; Macrory (n 3).

${ }^{173}$ Evidence to the Joint Committee (n 42) 143 (Evidence of Robin Mortimer).

${ }^{174}$ DEFRA (n 7) 54.

${ }^{175}$ Evidence to the Joint Committee (n 42) 329 (Evidence of Andrew Dlugolecki).

${ }^{176}$ McMaster (n 53) 117.

177 ibid 117-8.

${ }^{178}$ Evidence to the Joint Committee (n 42) 86-87 (Evidence of Graham Stuart MP).

179 ibid 329 (Evidence of Andrew Dlugolecki).

180 ss $11,27(2)$.

${ }^{181}$ Evidence to the Joint Committee (n 42) 329 (Evidence of Andrew Dlugolecki). However, arguably, such costs should be compared to the much larger long-term costs to the UK that would result from delaying decarbonisation: Committee on Climate Change (n 31) 66.

${ }^{182}$ Assuming the efficacy of the permitted forms of emissions trading.

${ }^{183}$ Limited by s $17(2)$ of the Act to $1 \%$ of the carbon budget of the latter period.
} 
deemed to be owed to all who might suffer damage; criminal sanctions (proposal vi), meanwhile, he considers 'fanciful'. ${ }^{184}$

Putting aside the seventh and eighth proposals ${ }^{185}$ leaves the second proposal as perhaps the most attractive. First, it has a clear and definable basis: the value of carbon credits that would have to have been purchased to prevent the duty being breached. It also avoids the pitfalls of a financial penalty, and of storing up problems for the future. It is constructive, rather than punitive. It may well involve ordering government expenditure, but this should not itself be a bar to enforcement. ${ }^{186}$ The difficulty comes in ordering the allocation of potentially large sums of public money. (What would 'appropriate infrastructure' be?) If notions of non-justiciability were applicable here, all of the elements discussed would apply. To order, say, a construction scheme of renewable energy infrastructure would be complex; the consequences would be immense: polycentricity and questions of resource allocation abound. The court would be trespassing overtly and significantly on the central political functions of Government. If, as suggested in this article, notions of non-justiciability do not apply to remedies, the court is, in principle, free to overlook these characteristics. However, this article has also argued that the effect of such characteristics might well constitute an obstacle to effective enforcement, whether described in terms of non-justiciability or not.

A more creative, flexible and co-operative approach to remedies may be required. For example:

i) The court could order certain general steps to be taken, leaving the details to be decided by the Government. ${ }^{187}$ In this way, 'ownership' of the most nonjusticiable elements of a remedy might be retained by the Government.

ii) 'One solution might be for the courts to evolve more flexible remedies, such as requiring a public authority to report back to the court as to how it is carrying out its public duties'. ${ }^{188}$

iii) More punitive measures could perhaps (at the same time) be imposed in 'suspended' form, to allow the Government a chance to take more constructive remedial measures. ${ }^{189}$

\footnotetext{
${ }^{184}$ McMaster (n 53) 117.

185 These must also be fanciful. For one thing, they run counter to a central theme of the Act - that successive Governments (not any single Government) share in the continuing obligation to reduce GHG emissions.

${ }^{186}$ Woolf and others (n 49) 294.

187 ibid ch 5-071.

188 Purdue (n 95) 502.

${ }^{189}$ Based on an innovation of the Supreme Court of Canada: see King (n 29) 284.
} 
To apply these suggestions to the example above: instead of a court ordering investment in a specific programme of action, it could order the Government to develop such a programme (perhaps within constraints outlined by the court), and to demonstrate to the court at certain intervals how that programme was being implemented. Such an approach would not be entirely without precedent. ${ }^{190}$ In the meantime, the court could allow excess emissions to be 'rolled forward' into future periods (akin to proposal iii, above) so that total emissions would not increase, while also reserving its ability to impose more punitive measures if the Government failed to comply with the court's remedial measures by a predetermined time. The purpose of this example is not to second-guess what a court might order in the event that a carbon budget was breached, but to demonstrate that it would be within its capacity to order a remedy that was both constitutionally appropriate and genuinely effective.

\section{E. CONCLUSION}

To return to Lord Denning's quote, ${ }^{191}$ there is in general a mismatch between the extent of public duties and the means that the courts have at their disposal to enforce them. The emergence of outcome duties (of which the Act's primary duties are examples) only exacerbates this problem, and demands an 'amplified' judicial response. I have argued that the duties under the Act which determine how carbon budgets are set and amended should be interpreted purposively. This will help to ensure that the carbon budgets are anchored sufficiently strongly to the 2050 target. Although the obstacles to the effective enforcement of the Act's primary duties are routinely described by commentators in terms of nonjusticiability, I have suggested that this framework of analysis does not, at least in its usual form, provide a satisfactory explanation of the real obstacles to enforcement. This is because non-justiciability tends not (overtly at least) to 'operate' at the remedies stage of a judicial review claim, yet it is at this stage that the obstacles to the enforcement of the Act's primary duties are found. Therefore, on any analysis, the prospect of effective enforcement of the Act's primary duties depends on the courts' willingness to craft effective and appropriate remedies. I have sought to demonstrate that such remedies need not be beyond the capacity of

\footnotetext{
${ }^{190}$ In $R(P) v$ London Borough of Newham [2004] EWHC 2210 (Admin), the High Court ordered the defendant local authority to prepare a 'draft pathway plan' for an individual's social care - in accordance with regulations - plus an adjournment of a specified duration 'in order, if necessary, for further debate about any compliance by the London Borough of Newham with its statutory obligations to take place' [14]. Potential parallels or interactions with s 13 of the Act (requiring the Secretary of State to prepare proposals and policies to meet carbon budgets) may be noted here. Related approaches to the judicial role (in the EU context of "new governance') are noted and explored in Joanne Scott and Susan Sturm, 'Courts as Catalysts: Re-thinking the Judicial Role in New Governance' (2006) 13 Columbia Journal of European Law 565.

${ }^{191}$ Text to (n 154).
} 
a court which in principle accepts the need for them. The Climate Change Act is noteworthy for establishing long-term and unambiguous duties on the Secretary of State to achieve quantified GHG emissions reductions by certain times. These duties are not only politically powerful, they are also capable of effective legal enforcement. 